\title{
A DNA Genealogy Solution to the Puzzle of Ancient Look-Alike Ceramics across the World
}

\author{
Anatole A. Klyosov, Elena A. Mironova \\ The Academy of DNA Genealogy, Newton, USA \\ Email: aklyosov@comcast.net
}

Received February $19^{\text {th }}, 2013$; revised March $24^{\text {th }}, 2013$; accepted April $16^{\text {th }}, 2013$

\begin{abstract}
Copyright (C) 2013 Anatole A. Klyosov, Elena A. Mironova. This is an open access article distributed under the Creative Commons Attribution License, which permits unrestricted use, distribution, and reproduction in any medium, provided the original work is properly cited.
\end{abstract}

\begin{abstract}
A puzzling similarity has been observed in some of the ceramics and figurines in several cultures in Eastern Europe (the Trypillia-Cucuteni culture, 6500 - 5500 years before present [ybp]), Thailand (the Ban-Chiang culture, between 7400 and $3800 \mathrm{ybp}$ ), China (the Yangshao culture, between 8000 and 4000 $\mathrm{ybp}$ ), North America (the Anasazi-Mogollon culture, between $7500 \mathrm{ybp}$ and present time). It is remarkable that the ceramics of these four cultures match each other in $17(45 \%)$ of the 38 indicators used to distinguish archeological ceramic piece in the comparative research. Remarkably, all four cultures with look-alike ceramics also use the swastika as a common symbol. We advance the hypothesis that all four cultures are connected by the Aryan (bearers of R1a) migrations between 5500 and $3000 \mathrm{ybp}$. While the Aryan migrations in Eurasia are well verified by DNA data, those in the Americas are not known as yet. Consideration of R1a haplotypes among Native Americans do not conflict with the hypothesis.
\end{abstract}

Keywords: Y-Chromosome; Mutations; Haplotypes; Haplogroups; SNP; Ceramics; Trypillia-Cucuteni; Ban-Chiang; Yangshao; Anasazi-Mogollon; Aryan Swastika

\section{Introduction}

This paper aims to explain a puzzling similarity in ceramics excavated from four Neolithic cultures and described in detail in Mironova (2013). The archaeological cultures, all agricultural, are:

- in Europe, the Trypillian, or Trypillia-Cucuteni culture, 6500 - 5500 years before present (ybp), northwest from the Black Sea, and between the rivers Dnestr on the West and Dnepr on the East

- in North-East Thailand, the Ban-Chiang culture, near the border with Laos, 7400 - 3800 ybp

- in China, the Yangshao culture, in the Huang He (Yellow River) basin, 8000 - 4000 ybp

- in North America, the Anasazi-Mogollon culture, located in Arizona, Utah, New Mexico, and Colorado, 7500- the present.

The dates given here are for the cultures, not for the ceramics, which - if dated at all - are often not reliably dated. All the cultures are ancient; the Trypillian culture, which belongs to the Proto-Slavic region of Vincha-Tordosh-Keresh-Cucuteni-Trypillia cultures of 8000 - $5000 \mathrm{ybp}$, reveals some similarity with ceramics and other artifacts of the Mesolithic Lepenski Vir culture in Serbia, dated at least 9400 - 8200 ybp using strontium isotope measurements (Boric \& Price, 2013).

It is remarkable that these cultures - separated by thousands of miles - designed ceramics and figurines that bear similarities that cannot be regarded as accidental.

\section{Features by which the Ceramic Artifacts Were Compared}

The features by which we assessed the ceramics were as- signed according to 38 features referred to technology, shape, function and ornament, the latter was based on classification by Golan (1991). We have found 17 similarities (45\%) among the ceramics of the said four cultures. Remarkably, all four cultures with look-alike ceramics also use the swastika as a common symbol. The 17 similarities include the technology of ceramics-making using clay ribbons (without potter's wheel) and polishing instruments, and finishing the surface: print of baskets, bast texture, engobe coating. Besides, they include common shapes and ornaments (designs, images, symbols) as follows: spoons with similar ornaments, anthropomorphic images, Great Goddess figure, Great Goddess face, "Eyes of Goddess"/volute sign, "eye" sign, Triglav (triskelion), spiral, double spiral, "Seeded soil" sign, triangles, S-shape ornaments, the W sign, apparent calendar functions of the vessels. Besides, some common characteristics were not mentioned in (Golan, 1991), such as swastika, "Tausen" symbol, figurine shape, figurine ornament, such as mouth open, position of arms and legs, exposed genitals. Most of similarities are in the design/symbols categories. Not all similarities are shown in the figures in this paper, for more detailed comparisons the reader is referred to (Mironova, 2013) containing more than 140 illustrations.

Let us consider some examples.

\section{Great Goddess Images and Figurines}

Certain patterns on ceramic vessels and on figurines of early agricultural civilizations are referred to in contemporary literature as "images of the Great Goddess". Typically, the Great Goddess is drawn from broken lines; she has a human body with spread limbs. This pattern occurs frequently in ornaments 
of the European Cucuteni-Trypillia and the Chinese Yangshao archaeological cultures (Figure 1).

The pattern, which resembles a human figure, follows certain rules: the "body" is drawn as a rectangle with a central red line; the limbs also have a central red line. In fact, these patterns are not really so much images as they are symbols. Often, the pattern has no head, or replaces the head with other symbols (see below).

In the four cultures we are considering, this Great Goddess image has been strikingly consistent through seven or eight millennia, and it occurs thousands of miles apart. We see it in the Anasazi-Mogollon cultures (Figure 2).

In China, in the Majiayao-Yangshao culture, 2300-2050 BC (Figure 3), we see a head of the Great Goddess on ceramics pieces a thousand years older than an American pot with a similar motif. In Figure 3, we see not only a head but a symbol built into it; this symbol is called "Seeded soil".

One pose of the Great Goddess reflects childbirth. It is found on many images, including those from the Lepenski Vir culture in the Balkans. In Figure 4 the Lepenski Vir Idol (upper (b)) is paired with an embossed female figure (a) from YangshaoMachang culture; the two figures have arms and legs in nearly identical positions.

Similar images of the Great Goddess are spread from the Balkans to South East Asia, and strikingly similar figurines are found in pre-Columbian cultures in America (Figure 5).

Most of the figurines hold their hands on the stomach, and in all of them the mouth is open. All expose genitals, most of

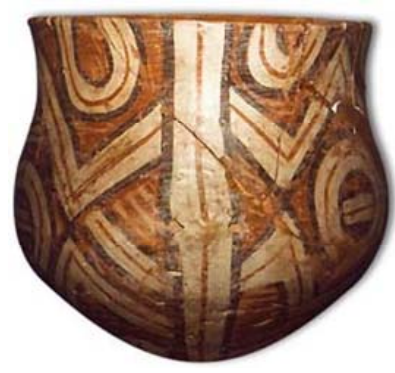

(a)

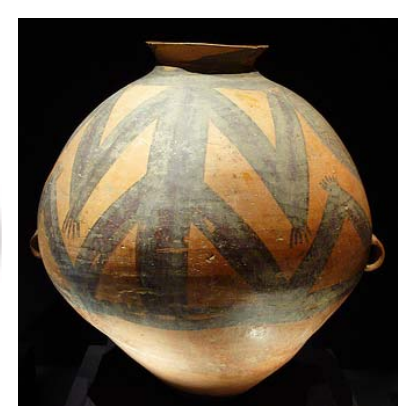

(b)
Figure 1.

A vessel with the symbolic image of the Great Goddess from Cucuteni (a); a very similar image of the Great Goddess on the vessel from Yangshao (b).

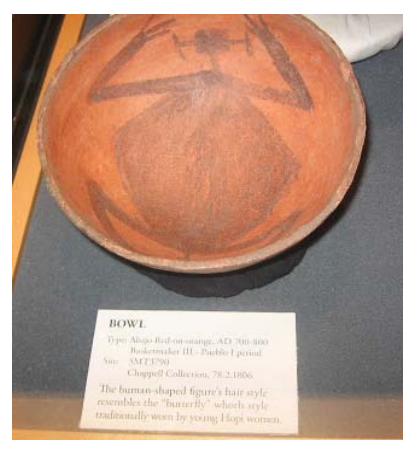

(a)

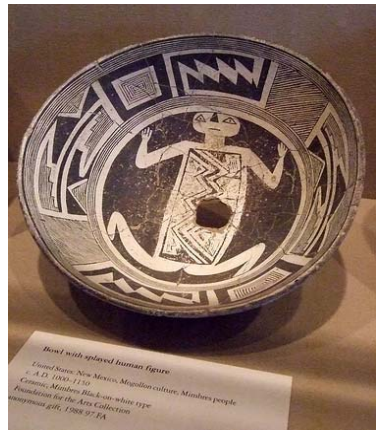

(b)
Figure 2.

Image of the Great Goddess. Anasazi culture (a). Mogollon culture (b), 1000-1150 BC, North America.

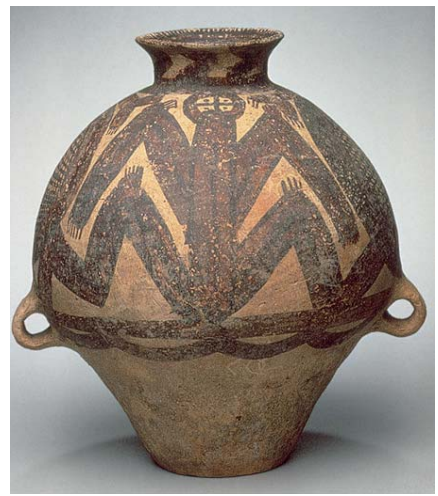

(a)

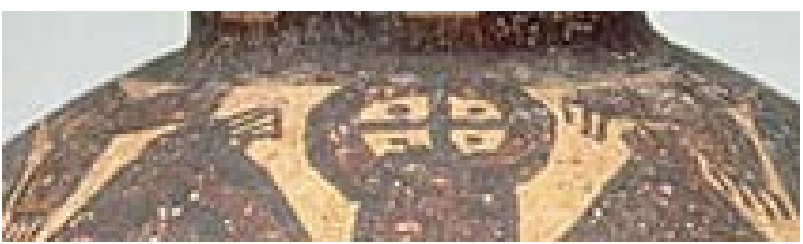

(b)

Figure 3.

Vessel from China (Yangshao) Gansu, culture Majiayao, Machang phase, 2300-2050 BC. The image below is a close-up of the head.

them have a symbol in a form of a letter M (or W) either carved or drawn in the collarbone area [not seen in the Figs here due to their small size, the reader is referred to (Mironova, 2013)]. It seems that Great Goddess figurines followed a common design.

\section{Triskelion (Triglav)}

The Triskelion, or Trinity, or Triglav (the triple Godhead) symbol is often seen on ceramics in the cultures mentioned above (e.g., Figure 6).

The Triglav sign in the both illustrations is not accompanied with any additional symbols. It is presented in the canonical form, with curved, spiral ends.

Figure 7 shows plates from the Chinese Majiayao and the American Anasazi cultures, both with the Triglav patterns, accompanied with other early agricultural symbols: the first bears a double spiral in the center along with the "eye" sign, repeated many times along the plate's rim, the second contains three disks filled with dots (the Seeded soil sign) and three birds around them (apparently, a sign of triple deities, triune God).

A vessel from the Ban-Chiang culture (Thailand) shows the pattern of Triglav as an isosceles triangle, formed with the ribbons as red lines (distinctive feature of Ban-Chiang archaeological culture). According to Golan, (1991), a triangle with three dots descends from the Great Goddess symbol (the triangle is a cloud, the three circles are the symbol of the triune God). One can also see a spiral, a symbol of early agricultural Neolithic civilizations, near the base of triangle (Figure 8).

These symbols are generally interpreted as representing 1) continuous development - a spiral, 2) vigilance-eye(s), 3) sustainable harvest - the Seeded soil pattern. All symbolize a triad of birth, life, and death (Golan, 1991). They might also symbolize the three phases of the agricultural cycle: seeding, growing, harvesting. 


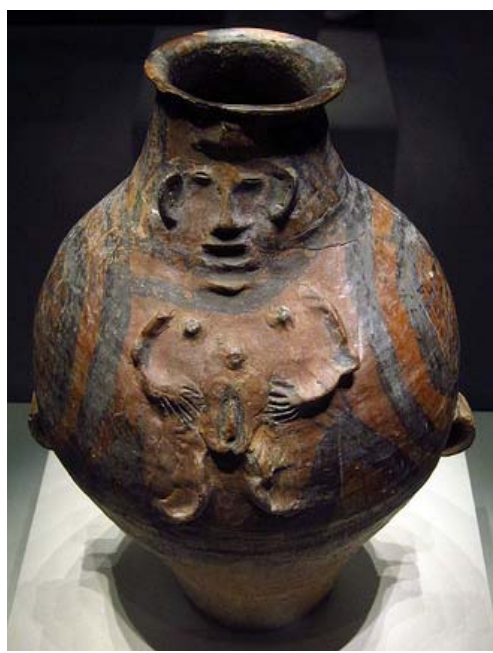

(a)

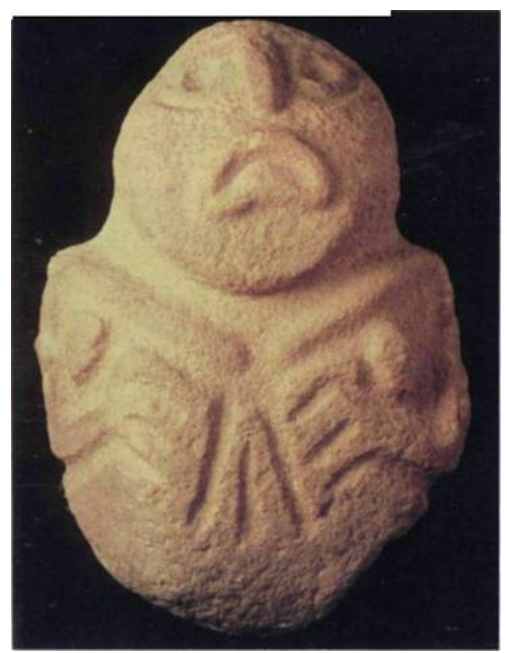

(b)

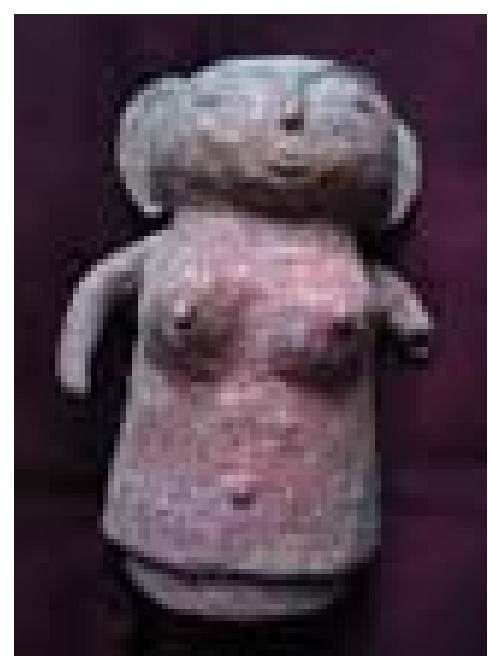

(c)

Figure 4.

Upper (a) a Chinese vessel (Yangshao-Machiang) with embossed female image. Upper (b) the Lepenski Vir Idol, $7^{\text {th }}$ millennium BC. (c) vase from Ban-Chiang, late stage, $300 \mathrm{BC}-200 \mathrm{AD}$.

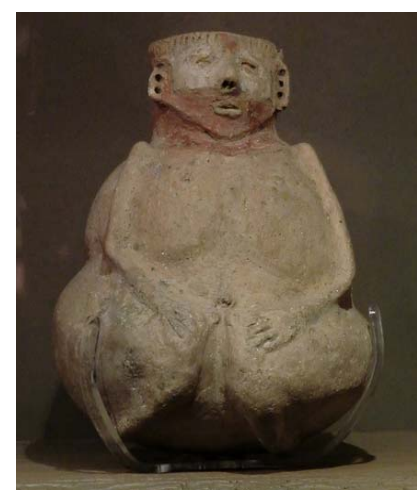

(a)

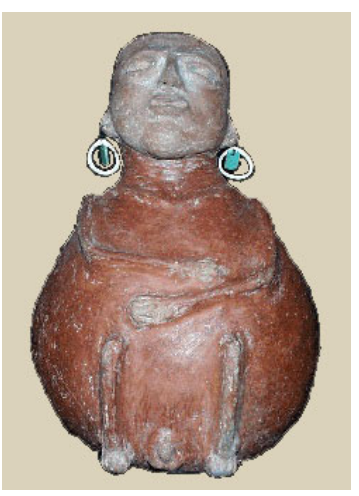

(b)

Figure 5.

(a) an Indian idol from the Appalachians, Cherokee, North Carolina. (b) a female figure from Arizona.

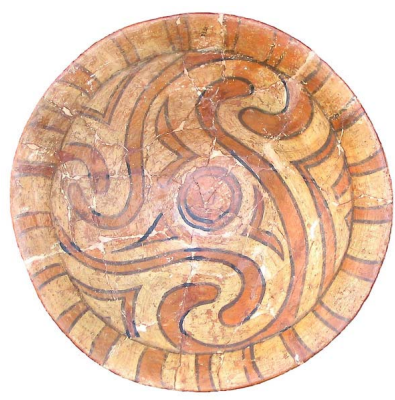

(a)

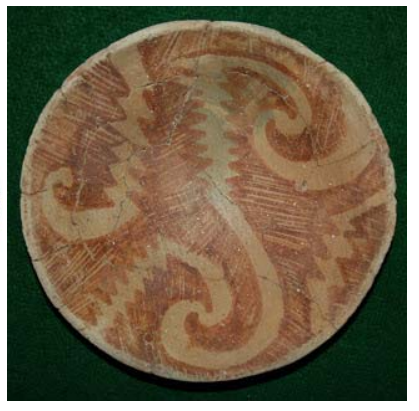

(b)

Figure 6.

(a) A plate from the East European Cucuteni culture with the Triglav sign; (b) A plate of the American Indian culture Hohokam (the Anasazi-Mogollon).

\section{Tausen}

The "Tausen" symbol, which is apparently related to harvesting, has been identified on clay seals of the Trypillia/Cu-

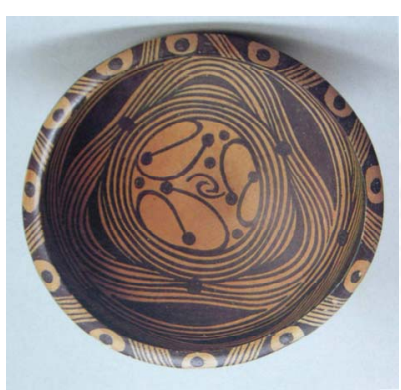

(a)

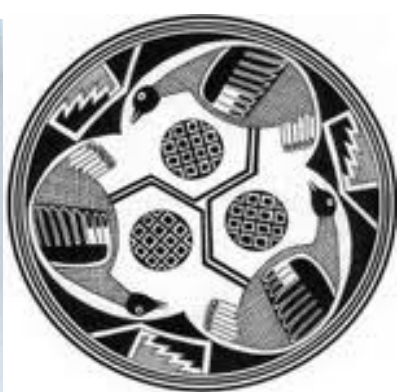

(b)
Figure 7.

(a) The Triglav image on a plate of the Neolithic culture Majiayao (China); (b) Stylized Triglav sign on a plate from Anasazi culture.

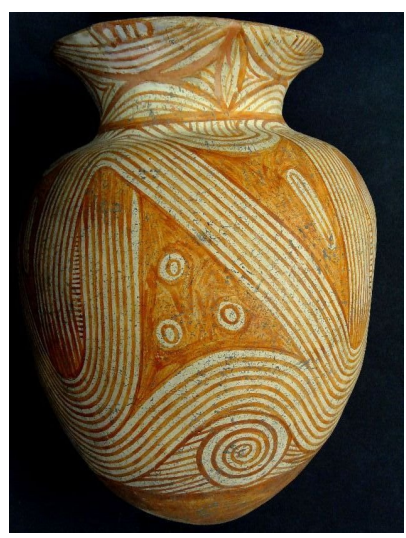

Figure 8.

A vessel from Ban-Chiang culture, with the Triglav sign.

cuteni and the Ban-Chiang cultures (Figure 9).

Figure 10 shows similar Tausen pattern in the Yangshao culture.

The Tausen sign is common in the Anasazi-Mogollon culture in America (Figure 11). 


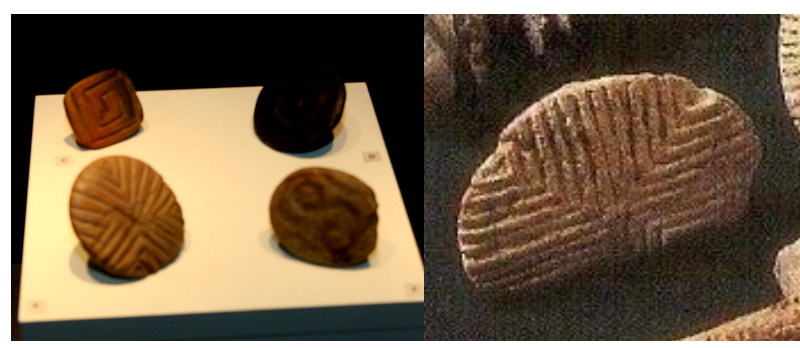

(a)

(b)

Figure 9.

Seals from Cucuteni (a) and Ban-Chiang (b).

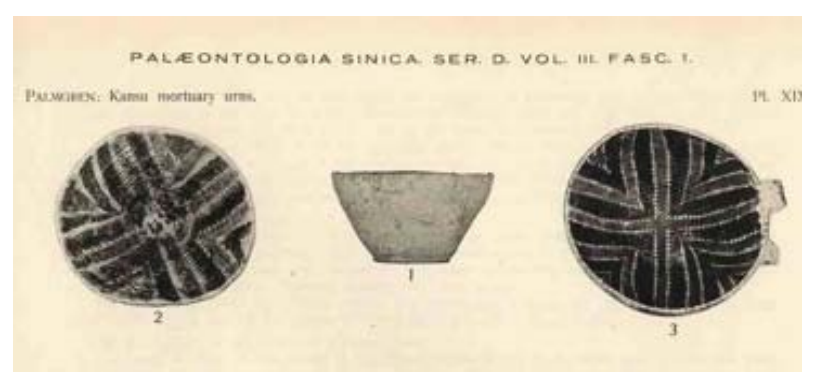

Figure 10.

The "Tausen" sign on ceramics from Yangshao.

Commonly, the Tausen pattern is used on concave shapes, on plates and cups in particular. It might have been connected with the richness of the harvest (see also Figure 12).

\section{Discussion}

\section{A DNA-Genealogy-Based Hypothesis}

How do we explain the presence of look-alike ceramics and figurines in four distinct and widely separated archeological sites?

Two answers have been predicated:

1) The artifacts are random in their origin; all similarities are accidental.

2) The artifacts are products of similar design, technology, and symbol. In other words, they have a common source.

The first statement is unlikely. So, let us consider possible explanations for the similarities of artifacts which are so distinct in geography. A possible explanation is that an ancient culture initiated certain ceramic designs and patterns, and that cultures in Eastern Europe, China, Thailand, America are "derivative" or "descended" from the designs of that ancient culture. This connection could be the result of physical migrations, or demic diffusion. The idea of diffusion from Europe or China to the New World is the most difficult to imagine. But here, DNA becomes useful. If the basic features of a set of artifacts were initially created as an "intellectual property" by an ancient tribe, is it possible to trace the creating tribe using Y-chromosomal haplogroups? When and where did the creative tribe live when the ceramic designs and symbols were being shaped? Do we know about migrations of any tribe or haplogroup which had connections to Eastern Europe, China, Thailand, and America many thousands of years ago?

A preliminary answer is yes. We do know of a haplogroup which migrated from East Europe to South-East Asia, and-in some conjectural accounts-from China and Europe to America. According to the work of Klyosov (2009a) and Klyosov

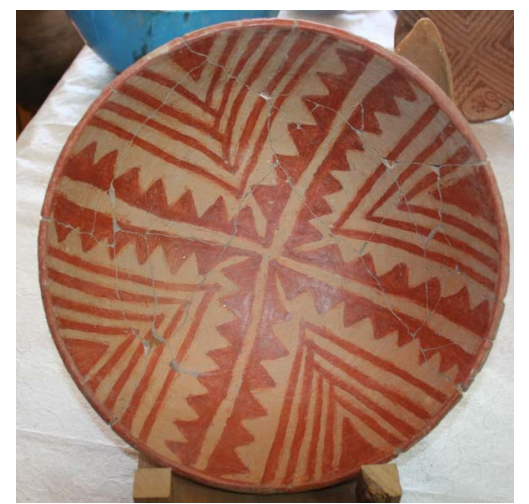

(a)

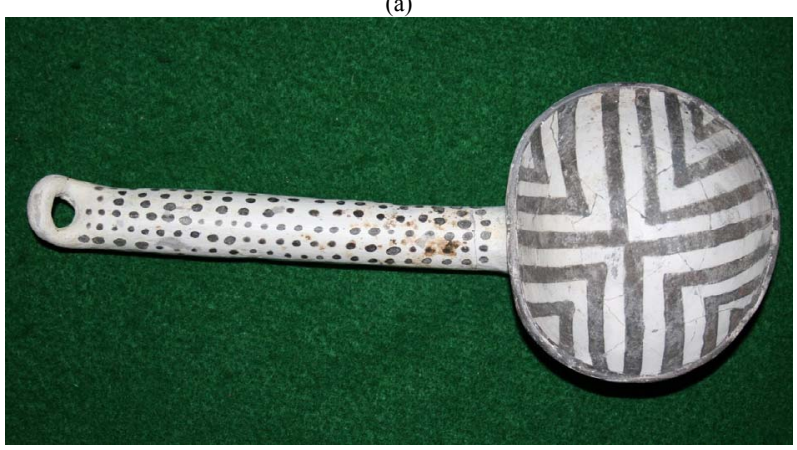

(b)

Figure 11.

The sign "Tausen" on a plate from the Mogollon culture in America (a), and on a spoon from the Anasazi (b).

and Rozhanskii (2012), haplogroup R1a arose in Central Asia, approximately 20 thousand years before the present. It made a long migration westward, (via Tibet, Hindustan, the Iranian plateau, Anatolia) and arrived in the Balkans around $10-9000$ ybp. This is seemingly the Lepenski Vir culture with its Europeoid (Caucasoid) excavated skeletons, and their strontium isotopes datings (see above). Among the chain of possible derivative cultures we see Trypillia-Cucuteni of 6500 - 5500 ybp. The R1a-Z93 subclade (South Eastern branch) arose 5700 ybp; its concurrent Z283 subclade (Eurasian branch) subclade arose 5500 ybp (Rozhanskii \& Klyosov, 2012), and they migrated eastward from Europe to the Russian Plain and further east, to Altai, Mongolia, China. Skeletal remains of the R1a haplogroup were excavated 3000 kilometers east of Ural Mountains, slightly north of Mongolia and China, dated 3800 - 3400 ybp (Keyser et al., 2009). The remains were identified as belonging to the R1a-Z93-L342.2-L657 subclade (Klyosov, 2013), which came to India and Iran about 3600 ybp. Also, R1a bearers might have migrated from Europe eastward 5000 years ago or even before that, and contributed to the Afanasievo culture in the Altai area, which overlaps the present day Russian and Chinese Altai regions, north of the Tarim basin. This migratory connection of R1a bearers to East Europe and China might explain the penetration of ceramics and figurine design from the Trypillian culture to the South East Asian cultures. The Ban-Chiang culture could have borrowed the art of ceramics and figurines from China. This art and craftsmanship could also have been brought to China and Thailand with the Aryans some 4000 - 3500 years ago, via the Andronovo culture. Except for R1a, no other haplogroup could have connected Eastern Europe 


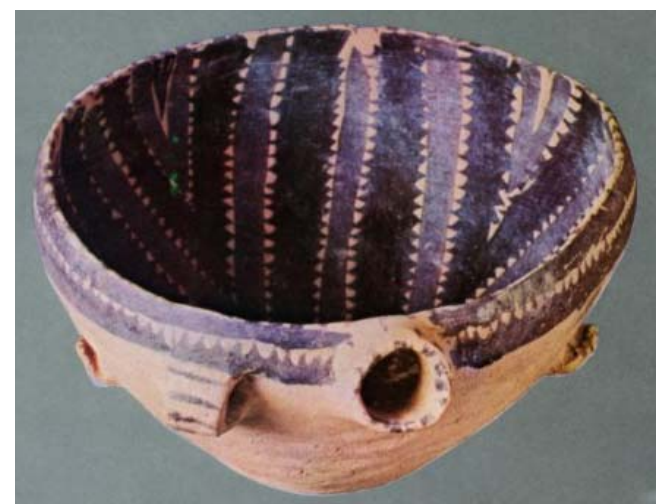

Figure 12.

Cup with the "Tausen" sign from the Yangshao culture, China.

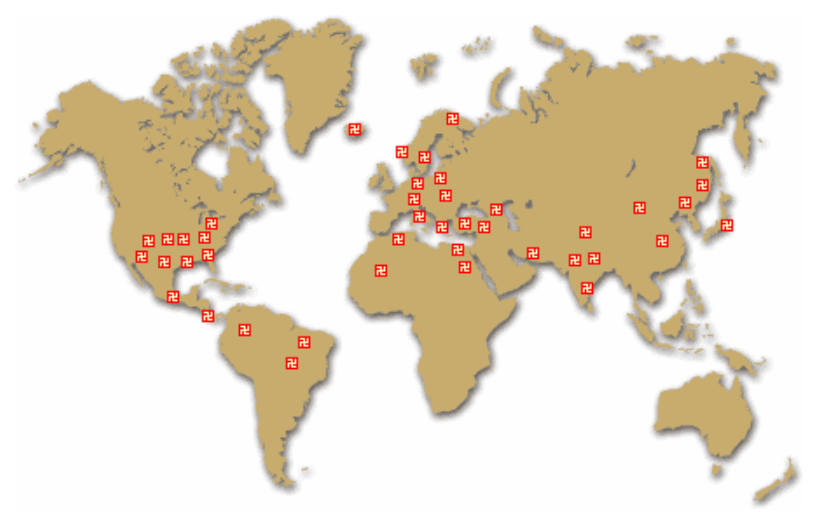

Figure 13.

The map of swastika as a characteristic feature of ancient cultures (Thomas Wilson, Curator, Department of Prehistoric Anthropology, US National Museum. 1894)

and China/Thailand. Haplogroup I is absent in South-East Asia, as is haplogroup $\mathrm{R} 1 \mathrm{~b}$; haplogroups $\mathrm{O}$ and $\mathrm{C}$ are absent in Europe, as are South-East Asian haplogroups N, and D.

A more difficult task is to build North America into the migration system we have posited. In addition to the Great Goddess, the Triglav, and the Tausen symbols used in Anasazi-Mogollon ceramics, the swastika is often used (Figure 13). A skeptic might say that the swastika could have been introduced randomly in South America among Maya, and in North America, in Navajo and Anasazi tribes, and in other tribes in the Americas, and among the Aryans, and in Trypillia-Cucuteni, and in Ban-Chiang culture. However, that degree of pure accidents is next to impossible, particularly when accompanied with similar ceramics.

\section{Swastika as an Argument of the Aryan Culture and Their Descendants}

Thomas Wilson, in his study of the swastika (1894), discussed a multitude of swastika images from various excavations, including swastikas of the Etruskans, swastikas of Indians in Hindustan, swastikas in Latin America (Maya, Nicaragua and others), swastikas of native Americans from what is now known as Ohio, Arkansas, and Kansas. How the swastikas got to all these places is something of a mystery.

Looking at the map in Figure 13, one can see that most of

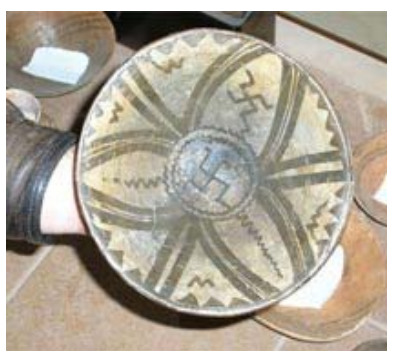

(a)

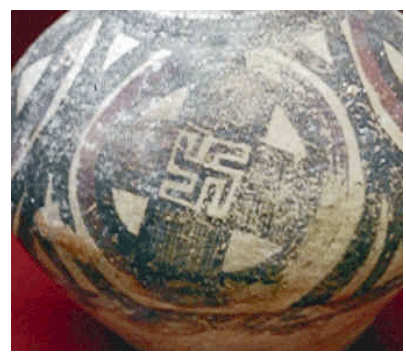

(b)
Figure 14.

Swastika on a plate from the Trypillia culture (a). The image shows the $\mathrm{W}$ (or M) sign, which is known on ceramics of the Ban-Chiang and Lepensky Vir cultures. Swastika on a vessel of the Yangshao culture, China (b).

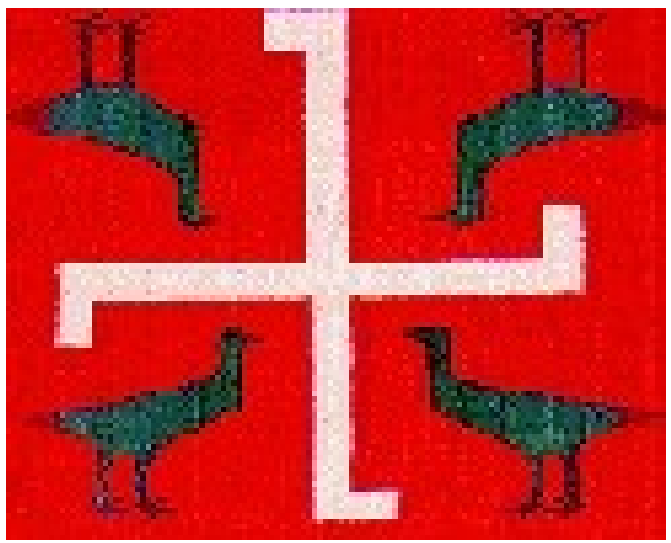

Figure 15.

Swastika of Navajo tribe in America.

the marks there are related to already known migration routes (or military expeditions) of R1a bearers between 5000 and 2500 ybp. This includes the routes from Europe to Iran, India, and China. It includes travels to Scandinavia, Iceland (but not to neighboring Greenland), Mesopotamia, the Middle East, the Arabian Peninsula, and Egypt, but not southward in Africa. In addition, the map shows swastika images in North and South America. Could R1a bearers have arrived in America in ancient times? Legends and myths about pre-Christopher Columbus travels to America abound. There are legends about the Vikings who allegedly reached shores of America (Jones, 1986). There are legends about the lost fleet of Alexander the Great, which might have reached America (Gladwin, 1947; Dybovsky, 2011). There are legends that Chinese explorers made a journey to America (de Guignes, 1761; Menzies, 2004). These legends are not scholarly, but we should keep them in mind when we consider R1a among native Americans (see below).

Figures 14-17 show swastikas in the Trypillia, Ban-Chiang, Anasazi, and Mogollon ancient cultures, and in Navajo tribes, the last three in America.

The swastika has accompanied the Aryans in the course of their migrations from the Russian Plain to India, Iran, and the Middle East (Figure 18-20). The swastika was very common in Russia until it was chosen by Nazis as their main symmbol in the 1930s. Even traditional Russian lace which had been made for centuries with a swastika ornamentation (e.g., Figure 18) was stopped in the 1930s. 


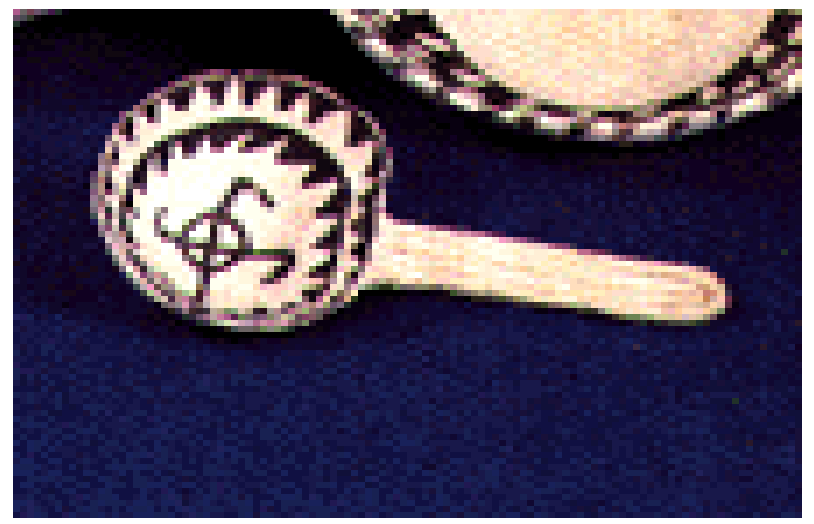

Figure 16.

Swastika on a spoon from the Anasazi culture.

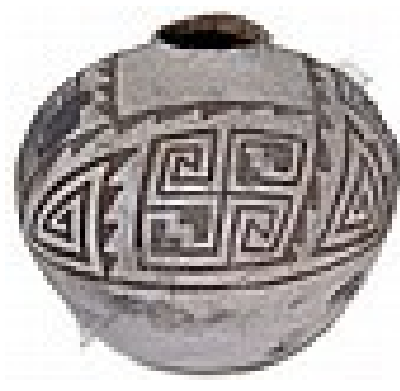

(a)

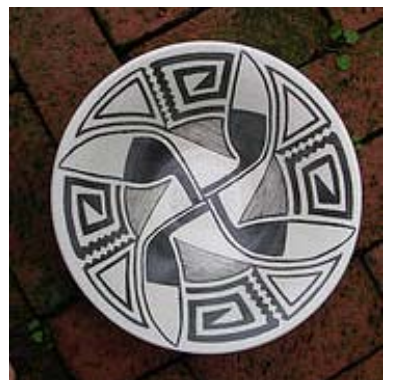

(b)
Figure 17.

Swastika on a vessel from the Anasazi culture (a) and on a plate from the Mogollon culture (b).

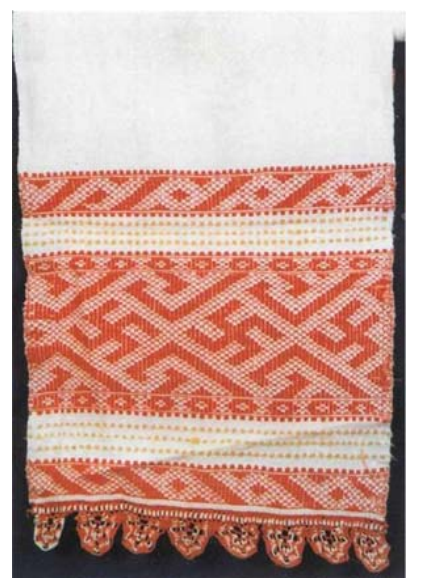

Figure 18.

Swastika on the Vologda lace, a traditional Russian ornament for millennia until the 1930 s.

\section{R1a in America}

Since the bearers of the R1a haplogroup used swastikas commonly, and since there is much use of the swastika in the Americas, it is, perhaps, possible that R1a bearers contacted ancient native Americans. What can DNA tell us?

One way to study the DNA record would be to look at unusual, "exotic" R1a haplotypes among Native Americans by testing ancient, excavated bones in America, in those regions

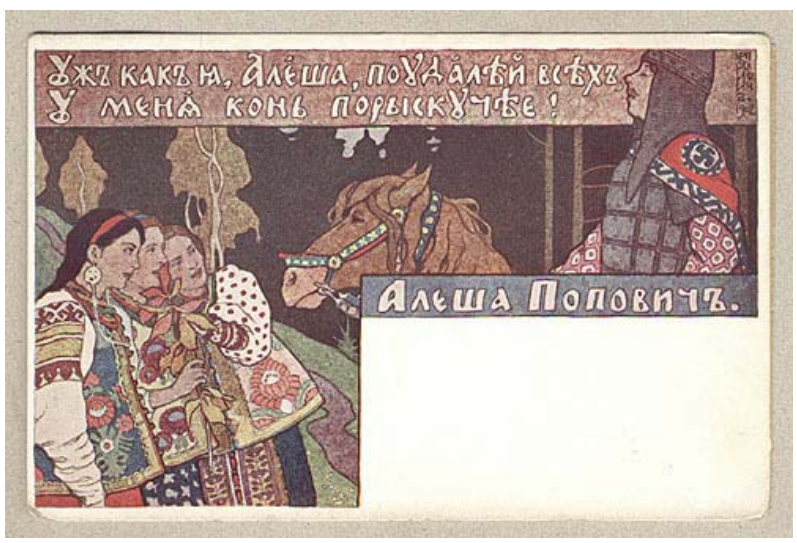

\section{Figure 19.}

Swastika on a scarf of a legendary Russian character (Alyosha Popovich) from the 12th century CE. The cartoon was made at the end of the 19th century, or copied from an old picture. Swastika was a common image in old Russia inherited from the Aryans on the Russian Plain.

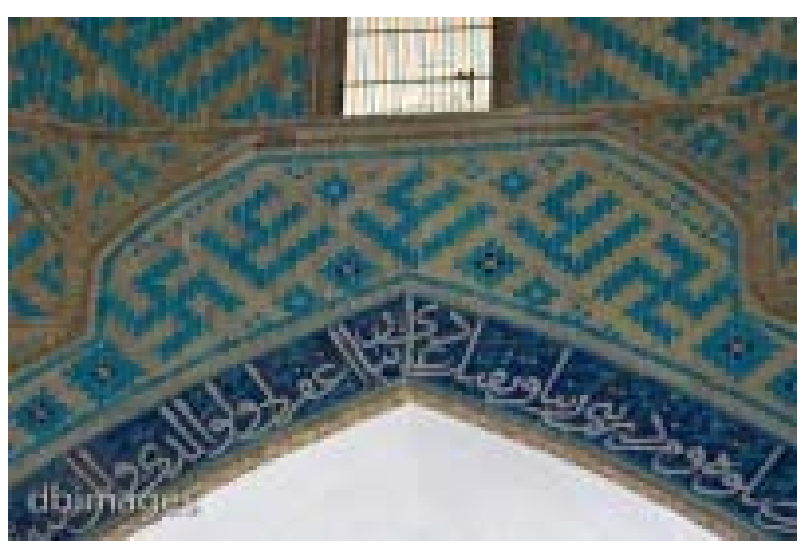

\section{Figure 20.}

Swastika in the Middle East, inherited from the Aryans there around 4000 - 3500 ybp. A fraction of the R1a-L342.2 haplogroup, the same subclade as that among the Hindu Indians, currently reaches $9 \%$ among the Arabs in the Middle East (Abu-Amero et al., 2009).

where the swastika was found. Unfortunately, there are no such data. Another way is to 1) analyze the haplogroups of Native Americans (NA) who have had Y-chromosome tests, 2) identify those who belong to haplogroup R1a, and 3) determine when their common R1a ancestor arrived in America. Unfortunately, relatively few Native Americans have had their $\mathrm{Y}$ chromosomes tested, and, as far as we know, none of them has been tested for extended haplotypes.

Though native Americans have been tested for Y-chromsomal haplogroups and (short) haplotypes far less frequently than have Europeans, we know that the most frequent haplogroup in NA is Q (Zegura et al., 2004; Bolnick et al., 2006; Mahli et al., 2008; O'Rourke \& Raff, 2010; Dulik et al., 2012). Haplogroups Q, R, and C, account for $95 \%$ of all Native American Y-chromosomes. In one study, 558 NA from the three main language groups-Eskimo-Aleut, Na-Dene, and Amerind-76\% had haplogroup Q, 13\% R, and 6\% C (Zegura et al., 2004). In another study of 281 haplotypes of Native Americans in the Central and Eastern regions of the United States (Bolnick et al., 2006) - where most of the decorative swastikas have been found-45\% had haplogroup Q, 31\% R1, $8 \% \mathrm{C}$, and 16\% "other". A haplotype tree for available R1- 


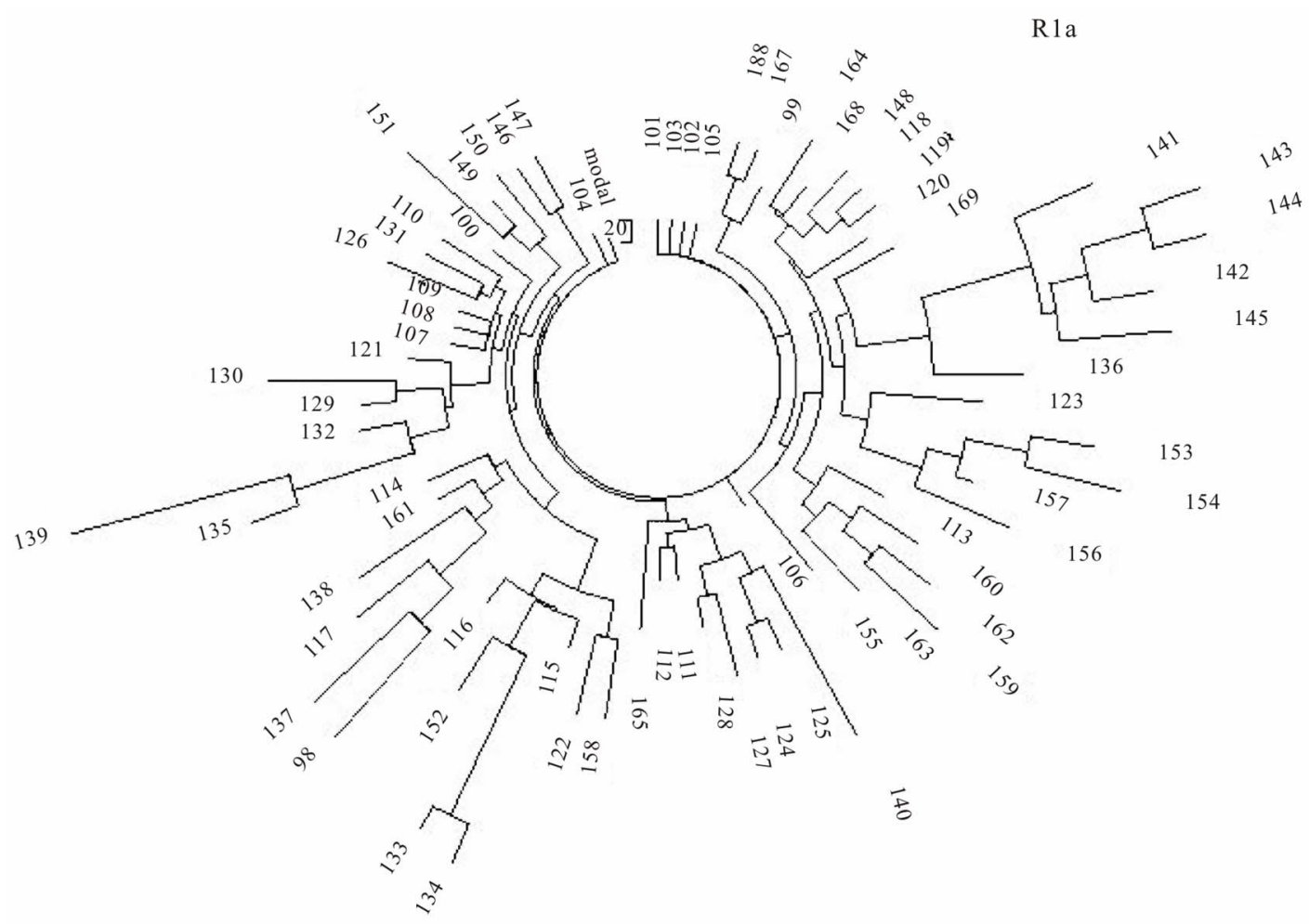

Figure 21.

A 10 marker haplotype tree of 72 Native Americans who belonged to the R1-M173 haplogroup (and/or any downstream haplogriopus). The tree was composed from data in (Bolnick et al, 2006). A branch in the upper-right part belongs to R1a haplogroup. Composition and analysis of haplotype trees is explained in (Klyosov, 2009b; Klyosov and Rozhanskii, 2012).

M173 haplotypes is shown in Figure 21. It should be noted that "R1" here means undifferentiated R1 (if any), R1a and R1b.

Since Bolnick et al. (2006) did not resolve the upstream haplogroup R1 into R1 itself, and sub-groups R1a, R1b, we had to rely on our phylogenetic program to resolve the tree into branches. Indeed, one branch in Figure 21, in the upper right side, has been identified as an R1a subgroup, with a distinct DYS392 = 11 (the penultimate allele below), such as in \#\# 141-144 in Figure 21:

$132516101113 \times$ X 11131116

$132516101114 \times$ X 10131117

$132516101114 \times$ X 10141117

132516101114 X X 11141117

The rest of haplogroups in the tree have DYS392 $=13$ or 14 (as in \#145 in the tree, along with many others), which might be either R1, or R1b, or an archaic R1a, with the age of a common ancestor 6000 years or more. Unfortunately, the problem cannot be resolved without a direct typing of Y-chromosomes to haplogroups and their subclades. In general, the overall shape of the tree indicates a highly heterogeneous origin of the haplotypes, which might certainly include men descended from ancient common ancestors who belonged to the R1 haplogroup with downstream subclades (including R1a) among native Americans.

We conclude that available data do not conflict with the hypothesis that there were some Rla bearers-unknown to us as yet - who arrived on the shores of the New World and brought with them ceramic designs and sacred symbols known in East Europe and South East Asia. This conjecture is supported to some degree by the DNA record available to us today. Al- though our hypothesis needs further testing, it is a starting point for explaining the remarkable similarities of ceramics in four widely spaced archeological sites.

\section{Acknowledgements}

The authors are indebted to Dr. Judith Remy Leder for her valuable help with the preparation of the manuscript.

\section{REFERENCES}

Abu-Amero, K. K., Hellani, A., Gonzalez, A. M., Larruga, J. M., Cabrera, V. M., \& Underhill, P. A. (2009). Saudi Arabian Y-chromosome diversity and its relationship with nearby regions. $B M C$ Genetics, 10, 1959. doi:10.1186/1471-2156-10-59

Bolnick, D. A., Bolnick, D. I., \& Smith, D. G. (2006). Asymmetric male and female genetic histories among Native Americans from Eastern North America. Molecular Biology and Evolution, 23, 21612174. doi: $10.1093 / \mathrm{molbev} / \mathrm{ms} 1088$

Boric, D., \& Price, T. D. (2013). Strontium isotopes document greater human mobility at the start of the Balkan Neolithic. Proceedings of the National Academy of Sciences, 110, 3298-3303. doi:10.1073/pnas.1211474110

Bruce, V., \& Young, A. (1998). In the eye of the beholder: The science of face perception. Oxford: Oxford University Press.

De Guignes, J. (1761). Recherches sur les Navigations des Chinois du Cote de l'Amerique, et sur quelques Peuples situés a l'extremite orientale de l'asie, cit. In J. Needham (Ed.), Science \& civilization in China (Vol. 4, No. 3, p. 782). Cambridge: Cambridge University Press.

Dulik, M. C., Owings, A. C., Gaieski, J. B., Vilar, M. G., Andre, A., Lennie, C., Mackenzie, M. A. et al. (2012). Y-chromosome analysis 
reveals genetic divergence and new founding native lineages in Athapaskan- and Eskimoan-speaking populations. Proceedings of the National Academy of Sciences, 109, 8471-8476.

doi:10.1073/pnas.1118760109

Dybovsky, A. P. (2011). A marine reconstruction of an unknown journey of Alexander the Great fleet in 323-321 BC. Proceedings of Academy of DNA Genealogy, 4, 467-501.

Gladwin, H. S. (1947). Men out of Asia. New York: McGraw-Hill Book Company.

Golan, A. (1991). Myth and symbol. South Deerfield, MA: Schoen Books.

Jones, G. (1986). The Norse Atlantic saga: Being the Norse voyages of discovery and settlement to Iceland, Greenland, and North America. Oxford: Oxford University Press.

Kemp, B. M., González-Oliver, A., Malhi, R. S. Monroe, C., Schroeder, K. B., McDonough, J., Rhett, G. et al. (2009). Evaluating the farming/language dispersal hypothesis with genetic variation exhibited by populations in the Southwest and Mesoamerica. Proceedings of the National Academy of Sciences, 107, 6759-6764.

Keyser, C., Bouakaze, C., Crubezy, E., Nikolaev, V. G., Montagnon, D., Reis, T., \& Ludes, B. (2009) Ancient DNA provides new insights into the history of South Siberian Kurgan people. Human Genetics, 126, 395-410. doi:10.1007/s00439-009-0683-0

Klyosov, A. A. (2009a). DNA Genealogy, mutation rates, and some historical evidences written in Y-chromosome. II. Walking the map. Journal of Genetic Genealogy, 5, 217-256.

Klyosov, A. A. (2009b). DNA Genealogy, mutation rates, and some historical evidences written in Y-chromosome. I. Basic principles and the method. Journal of Genetic Genealogy, 5, 186-216.

Klyosov, A. A. (2013) Subclade R1a-L342-L657 beyond Ancient Urals. Proceedings of Academy of DNA Genealogy, 6, 446-451.
Klyosov, A. A., \& Rozhanskii, I. L. (2012) Haplogroup R1a as the Proto Indo-Europeans and the legendary Aryans as witnessed by the DNA of their current descendants. Advances in Anthropology, 2, 1-13. doi:10.4236/aa.2012.21001

Malhi, R. S., Gonzalez-Oliver, A., Schroeder, K. B., Kemp, B. M., Greenberg, J. A., Dobrowski, S. Z., Smith D. G., Resendez, A., Karafet, T., Hammer, M. et al. (2008). Distribution of Y-chromosomes among native North Americans: A study of Atha-Paskan population history. American Journal of Physical Anthropology, 137, 4412-4424.

Menzies, G. (2004). 1421: The year China discovered America. New York: William Morrow Paperbacks.

Mironova, E. A. (2013). The same ceramics, matching ornaments, and identical signs on artifacts of Neolithic, Eneolithic, and Bronze cultures in Europe, Asia, and North America. Proceedings of Academy of DNA Genealogy, 6, 267-373.

O'Rourke, D. H., \& Raff, J. A. (2009). The human genetic History of the Americas: The final frontier. Current Biology, 20, R202-R207. doi:10.1016/j.cub.2009.11.051

Rozhanskii, I. L., \& Klyosov, A. A. (2012) Haplogroup R1a, its subclades and branches in Europe during the last 9000 Years. Advances in Anthropology, 2, 139-156. doi:10.4236/aa.2012.23017

Wilson, T. (1894) The Swastika. Reprinted in 2003, by Northvegr and A. Odhinssen. www.nazi.org.uk/german-myths-pdfs2/TheSwastika1.pdf

Zegura, S. L., Karafet, T. M., Zhivotovsky, L. A., \& Hammer, M. F. (2004). High-resolution SNPs and microsatellite haplotypes point to a single, recent entry of Native American Y-chromosomes into the Americas. Molecular Biology and Evolution, 21, 164-175. doi:10.1093/molbev/msh009 


\section{Appendix}

The following reference data have been selected for ceramic images:

Figure 1(a):

http://www.culture.gouv.fr/fr/arcnat/harsova/en/echan2.htm

Figure 1(b):

http://www.flickr.com/photos/rosemania/3267206463/siz es/m/in/photostream/

Figure 2(a):

http:/www.flickriver.com/photos/mharrsch/360637566/

Ceramic Bowl Mogollon culture Mimbres people 1000-1150 CE New Mexico United States

Figure 2(b):

http://4cornershikesancients.blogspot.ru/2010/01/potteryshards-on-trail.html

Figure 3:

http://www.metmuseum.org/toah/works-of-art/1992.165. 8

Figure 4(a):

http://www.flickr.com/photos/byrnzie28/6021766329/siz es/m/in/photostream/

Figure 4(b):

http://thehistoryofeuropepodcast.blogspot.ru/2012/05/rat her-unhappy-lepenski-vir-sculptures.html

Figure 4(c):

http://picasaweb.google.com/109023056224656515739/

Asia\#

Figure 5(a):

http://www.microwavedpepys.com/?cat $=8$ \&paged $=4$

http://www.cherokeemuseum.org/exhibits-paleo.htm

Figure 5(b):

http://www.t-rat.com/Pages/ArchaeologyContinue.html

Figure 6(a):

http:/glyphika.blogspot.ru/2012/03/ancient-spirals-not-ju st-celtic.html

Figure 6(b):

http://rarepotteryinfoblogspot.blogspot.ru/2011/07/hohok am-snaketown-red-on-buff.html

Figure 7(a):

http://iridescent.icograda.org/journal/journal14.php

Figure 7(b):

http://www.discoverseaz.com/History/Archaic.html
Figure 8:

http://www.liveauctioneers.com/item/12531649_ban-chi ang-rouge-ceramic-pot

Figure 9(a):

http://en.wikipedia.org/wiki/Symbols_and_proto-writing _of_the_Cucuteni-Trypillian_culture

Figure 9(b):

http://smspostcard3.blogspot.com/2009/05/missing-thaila nd-ban-chiang.html

Figure 10:

http://www.chinaheritagequarterly.org/scholarship.php?s earchterm $=023 \_$yangshao.inc\&issue $=023$

Figure 11(a):

http://rarepotteryinfoblogspot.blogspot.ru/2012/05/mogol lon-pottery-cascabel-red-on-brown.html

Figure 11(b):

http://rarepotteryinfoblogspot.blogspot.ru/2011/06/anasa zi-mancos-black-on-white-ladle.html

Figure 12:

http://laudland.com/archives/1573

Figure 13:

http://elearning.zaou.ac.zm:8060/Symbolism/Swastika/T he\%20Swastika\%20-\%20Thomas\%20Wilson\%201894\% 20.pdf

Figure 14(a):

http://www.btb-net.com/main/75/tripllya-tsivlzatsinii-vi $\mathrm{mr}$

Figure 14(b):

http://www.chaz.org/Arch/China/Well/Well.html

Figure 16:

http://www.rain.org/campinternet/southwest/anasazi-art2000.html

Figure 17 (a):

http://www.artfact.com/auction-lot/anasazi-pottery-181-p -uzcvwd6fud

Figure 17(b):

http://www.examiner.com/article/southwest-indian-relics -search-of-cash-part-i

Ban Chiang prehistoric pottery (2012) Prasat Museum, Bangkok Thailand, Southeast Asia, Asia. Electronic resource. http://www.profimedia.si/picture/ban-chiang-prehistoricpottery-prasat-museum-bangkok/0056250645/. 